\title{
PENINGKATAN KETERAMPILAN MENULIS TEKS CERITA FANTASI DENGAN MODEL DISCOVERY LEARNING DAN MEDIA AUDIO VISUAL PADA SISWA KELAS VII5 SMP NEGERI 3 AMBON
}

\author{
Astrit Vivi Souhuwat \\ Program Pendidikan Profesi Guru Bidang Studi Bahasa Indonesia Universitas Pattimura \\ e-mail: astri.souhuwat19@gmail.com
}

\begin{abstract}
Abstrak: Penelitian ini merupakan Penelitian Tindakan Kelas yang berjudul Peningkatan Keterampilan Menulis Teks Cerita Fantasi Menggunakan Model Discovery Learning dan Media Audio VisualPada Peserta Didik Kelas VII5 SMP Negeri 3 Ambon Tahun Ajaran 2019/2020. Penelitian ini bertujuan untuk meningkatkan proses pembelajaran, dan keterampilan menulis cerita fantasi pada siswa kelas VII 5 Sekolah Menengah Pertama Negeri 3 Ambon.

Dalam penelitian ini digunakan pendekatan pembelajaran melalui model Discovery Learning dan menggunakan media Audio Visual. Penelitian ini menggunakan pendekatan teori Riset Aksi Model John Elliot. Penelitian dilaksanakan dalam dua siklus. Subjek penelitian ini adalah kelas VII 5 yang terdiri dari 27 perserta didik. Teknik pengumpulan data menggunakan: 1) observasi, 2) tes, dan 3) dokumentasi. Teknik analisis data menggunakan deskriptif kuantitatif dan kualitatif.

Hasil penelitian Siklus I yang telah dilaksnakan, peserta didik yang memenuhi ketuntasan minimal dari ketiga aspek dalam menyusun cerita fantasi sebanyak 5 siswa atau sebesar $18,52 \%$, dan yang belum mencapai KKM ada sebanyak 22 siswa atau sebesar 81,48\%. Untuk siklus II yang dapat menyusun cerita fantasi dan tuntas KKM pada kelas VII5 sebanyak 22 peserta didik atau $81,48 \%$. Dan siswa yang belum tuntas sebanyak 5 peserta didik atau 18,52\%. Dari kedua penelitian ini didapatkan hasil bahwa ada peningkatan $62,96 \%$.
\end{abstract}

Kata Kunci: keterampilan menulis cerita fantasi, metode Discovery Learning, siswa kelas VII SMP 


\title{
ENHANCING SKILLS OF WRITING FANTASY STORY TEXT USING DISCOVERY LEARNING MODEL AND AUDIO VISUAL MEDIA IT VII5 GRADE STUDENTS IN NEGERI 3 AMBON
}

\author{
Astrit Vivi Souhuwat \\ Program Pendidikan Profesi Guru Bidang Studi Bahasa Indonesia Universitas Pattimura \\ e-mail: astri.souhuwat19@gmail.com
}

\begin{abstract}
This research is a Class Action Research entitled Improving the Skill of Writing Fantasy Story Texts Using Discovery Learning Models and Audio-visual Media To Students of Class VII5 of SMP Negeri 3 Ambon in Academic Year 2019/2020. This study aims to improve the learning process, and the skills to write fantasy stories in grade VII 5 students of Ambon 3 State Middle School.

In this study the learning approach is used through Discovery Learning models and using Audio Visual media. This study uses the John Elliot Model Action Research theory approach. The study was conducted in two cycles. The subject of this research was class VII 5 which consisted of 27 students. Data collection techniques use: 1) observation, 2) tests, and 3) documentation. Data analysis techniques using quantitative and qualitative descriptive.

The results of the Cycle I research that have been carried out, students who meet the minimum completeness of the three aspects in compiling fantasy stories as many as 5 students or $18.52 \%$, and those who have not reached KKM there are as many as 22 students or $81.48 \%$. For cycle II who can compile fantasy and complete KKM stories in class VII5 as many as 22 students or $81.48 \%$. And students who have not completed as many as 5 students or $18.52 \%$. From these two studies it was found that there was an increase of $62.96 \%$.
\end{abstract}

Keywords: fantasy story writing skills, Discovery Learning methods, VII graders of junior high school 


\section{A. PENDAHULUAN}

Mata pelajaran bahasa Indonesia pada kurikulum 2013 materi pelajaran ditekankan pada kompetensi berbahasa sebagai alat komunikasi untuk menyampaikan gagasan dan pengetahuan, peserta didik dibiasakan menyusun teks yang sistematis, logis, dan efektif melalui latihan-latihan penyusunan teks, serta peserta didik dikenalkan dengan aturan-aturan teks yang sesuai sehingga tidak rancu dalam proses penyusunan teks.

Pembelajaran berbasis teks tersebut dapat berupa teks lisan dan tertulis. Materi pelajaran bahasa Indonesia yang diajarkan untuk kelas VII adalah teks hasil observasi, teks tanggapan deskriptif, teks eksposisi, teks eksplanasi, dan teks cerita fantasi. Pembelajaran yang bersifat sastra hanya terfokus pada teks cerita fantasi. Sedangkan pembelajaran yang bersifat kebahasaan memiliki porsi yang cukup banyak.

Pembelajaran berbasis teks dimulai dengan meningkatkan pengetahuan seperti struktur, kaidah, dan makna suatu teks dilanjutkan dengan keterampilan menyajikan, menyusun, suatu teks tulis maupun lisan. Istilah 'menulis' (kurikulum KTSP) dalam kurikulum 2013 diganti dengan istilah 'menyusun'. Berdasarkan konsepnya, istilah 'menyusun' dalam salah satu kompetensi dasar kurikulum 2013 memiliki arti yang sama dengan konsep menulis. Tuntutan dalam kurikulum 2013, peserta didik harus mampu menyusun teks cerita fantasi dengan memerhatikan struktur teks cerita fantasi yang tepat dengan bahasa yang sesuai dengan kaidah penulisan cerita fantasi yang berlaku (Winda Hayu Pamungkas, 2014:3).

Menulis merupakan salah satu kegiatan yang menjadi komponen utama dalam pembelajaran Bahasa Indonesia. Aktivitas menulis merupakan suatu bentuk manifestasi kemampuan dan keterampilan berbahasa yang paling akhir dikuasai oleh siswa setelah kemampuan mendengarkan, berbicara, dan membaca. Pembelajaran menulis di sekolah pun diberikan secara bertahap disesuaikan dengan tingkat kemampuan siswa.

Menulis sebagai suatu keterampilan berbahasa, yaitu suatu keterampilan berbahasa yang dipergunakan untuk berkomunikasi secara tidak langsung, tidak secara tatap muka dengan orang lain. Secara luas dapat dikatakan bahwa komunikasi adalah suatu pengiriman dan penerimaan pesan-pesan yang pasti terjadi (Tarigan, 1982:13).

Cerita fantasi merupakan salah satu genre karya sastra yang berbentuk prosa fiksi yang menyangkut persoalan kehidupan dan berisi satu peristiwa atau kejadian yang menarik untuk diceritakan. Menurut Jakob Sumardjo (dalam Kusmayadi 2010:7) Cerita fantasi adalah cerita atau rekaan fiktif. Artinya bukan berupa analisis argumentasi dan peristiwanya tidak benar-benar telah terjadi serta relatif pendek. Kependekan sebuah cerita fantasi bukan karena bentuknya jauh lebih pendek dari novel, melainkan karena aspek masalah yang diceritakannya.

Proses menyusun teks cerita fantasi secara tertulis memerlukan sebuah rangsangan agar dapat meningkatkan ketertarikan peserta didik, serta dapat merangsang daya imajinasi peserta didik. Ketertarikan tersebut harus diasah sejak dini, karena dengan ketertarikan untuk menyusun teks cerita fantasi tersebut peserta didik dapat menyalurkan daya imajinasi. Imajinasi dapat berasal dari pengalaman hidup sesorang, baik pengalaman yang langsung dirasakan maupun pengalaman yang berasal dari orang lain. 
Berdasarkan observasi dan wawancara yang dilakukan peneliti dengan guru pengampu mata pelajaran bahasa Indonesia kelas VII5 SMP Negeri 3 Ambon, diketahui bahwa dalam pembelajaran menyusun teks cerita fantasi secara tertulis masih perlu ditingkatkan. Ada beberapa faktor yang membuat peserta didik kesulitan dalam pembelajaran keterampilan menyusun teks cerita fantasi secara tertulis. Beberapa kesulitan yang dialami peserta didik antara lain.

Pertama, peserta didik sulit untuk mengembangkan gagasan menjadi sebuah teks cerita fantasi. Sebenarnya peserta didik sudah memiliki gagasan, namun mereka merasa bingung apakah gagasan tersebut cocok jika dijadikan sebuah cerita fantasi.

Kedua, peserta didik merasa bingung dalam menyusun teks cerita fantasi karena peserta didik belum memperhatikan struktur teks cerita fantasi secara benar. Hal ini dapat dipengaruhi oleh penguasaan teori peserta didik. Dapat juga dipengaruhi oleh penggunaan metode kurang tepat. Selain itu, faktor yang memengaruhi adalah pembelajaran yang kurang menarik dan memotivasi peserta didik. Peserta didik merasa bosan dan jenuh. Hal ini juga dapat dipengaruhi oleh psikologi peserta didik SMP yang merasa cepat bosan.

Ketiga, penggunaan model dan media yang kurang bervariasi dalam pembelajaran menyusun teks cerita fantasi. Penggunaan model pembelajaran yang tepat untuk membelajarkan menyusun teks cerita fantasi kepada peserta didik sangat penting. Tidak hanya model pembelajaran yang dibutuhkan dalam mengajarkan kompetensi menyusun teks cerita fantasi, media pembelajaran pun sama penntingnya. Selain itu, penggunaan media juga dapat menentukan keberhasilan peserta didik dalam menyusun teks cerita fantasi. Untuk mengatasi hal-hal tersebut, guru harus mengambil langkah dalam proses pembelajaran menyusun teks cerita fantasi menggunakan model dan media tertentu yang sesuai sehingga dapat meningkatkan kemampuan menyusun teks cerita fantasi peserta didik.

Berdasarkan permasalahan yang ditemukan, peneliti memberikan solusi untuk menggunakan model Discovery Learning menggunakan media Audio Visual berupa cuplikan film fantasi sebagai upaya peningkatan kemampuan menyusun teks cerita fantasi untuk peserta didik kelas VII5 di SMP Negeri 3 Ambon. Siswa belum menggunakan bahasa tulis yang baik, masih ada siswa yang menggunakan bahasa keseharian (bahasa daerah).

Model Discovery Learning ini juga dapat dikolaborasikan dengan media dongeng yang nantinya dapat menjadi alternatif untuk meningkatkan keterampilan menyusun teks cerita fantasi pada peserta didik. Media adalah alat bantu apa saja yang dapat dijadikan sebagai penyalur pesan guna mencapai tujuan pengajaran. Untuk menunjang pembelajaran di dalam kelas, salah satu hal yang didapat digunakan yaitu media pengajaran. Dengan adanya media pengajaran dalam proses pembelajaran akan dapat membantu peserta didik belajar dengan lebih baik (Djamarah 2010: 121). Media Audio Visual dalam pembelajaran menyusun teks cerita fantasi dijadikan sebagai acuan, dimana tema dari dongeng akan dijadikan sebagai tema dasar penyusunan teks cerita fantasi. Oleh karena itu, dalam penelitian ini akan dibahas keterampilan menyusun teks cerita fantasi menggunakan model Discovery Learning dan media Audio Visual. Penggunaan model Discovery Learning dan media Audio Visual memiliki potensi yang baik untuk meningkatkan kemampuan peserta didik dalam menyusun teks cerita fantasi. Oleh karena itu, peneliti akan mengangkat hal tersebut dengan melakukan penelitian 
dengan judul "Peningkatan Keterampilan Menulis Teks Cerita Fantasi Dengan Model Discovery Learning dan Media Audio Visual Pada Peserta Didik Kelas VII5 SMP Negeri 3 Ambon".

\section{B. METODE PENELITIAN}

Metode penelitian secara umum diartikan sebagai cara ilmiah untuk memperoleh data dengan tujuan dan kegunaan tertentu, dimana cara ilmiah disini berarti suatu kegiatan penelitian itu didasarkan pada ciri-ciri keilmuan yaitu rasional, empiris, dan sistematis. Dalam penelitian ini, metode yang digunakan adalah metode penelitian tindakan kelas. Penelitian Tindakan Kelas disebut juga Classroom Action Reasearch. Penelitian tindakan kelas (PTK) merupakan suatu bentuk yang bersifat reflektif dengan melakukan tindakan-tindakan tertentu agar dapat memperbaiki dan meningkatkan praktek-praktek pembelajaran di kelas secara professional.

Penelitian Model John Elliot; apabila dibandingkan dua model yang sudah diutarakan di atas, yaitu Model Kurt Lewin dan Kemmis-McTaggart, PTK Model John Elliot ini tampak lebih detail dan rinci. Dikatakan demikian, oleh karena di dalam setiap siklus dimungkinkan terdiri dari beberapa aksi yaitu antara 3-5 aksi (tindakan). Sementara itu, setiap aksi kemungkinan terdiri dari beberapa langkah, yang terealisasi dalam bentuk kegiatan belajar-mengajar. Maksud disusunnya secara terinci pada PTK Model John Elliot ini, supaya terdapat kelancaran yang lebih tinggi antara taraf-taraf di dalam pelaksanan aksi atau proses belajar-mengajar. Selanjutnya, dijelaskan pula olehnya bahwa terincinya setiap aksi atau tindakan sehingga menjadi beberapa langkah oleh karena suatu pelajaran terdiri dari beberapa subpokok bahasan atau materi pelajaran. Di dalam kenyataan praktik di lapangan setiap pokok bahasan biasanya tidak akan dapat diselesaikan dalam satu langkah, tetapi akan diselesaikan dalam beberapa rupa itulah yang menyebabkan John Elliot menyusun model PTK yang berbeda secara skematis dengan kedua model sebelumnya.

Penelitian ini dilaksanakan dalam dua siklus, yaitu siklus I dan siklus II. Setiap siklus terdiri atas empat tahap, yaitu (1) perencanaan, (2) tindakan, (3) observasi, (4) refleksi. Observasi awal dilakukan agar peneliti mengetahui kondisi peserta didik di dalam kelas, hambatan yang dialami oleh peserta didik saat mengikuti pembelajaran beserta penyebab dari masalah-masalah tersebut

\section{Prosedur Tindakan Siklus I}

Tahap perencanaan siklus I dilakukan peneliti sebagai upaya memecahkan masalah berdasarkan observasi awal. Pada tahap ini, peneliti berkoordinasi dengan guru mata pelajaran bahasa Indonesia mengenai waktu pelaksanaan penelitian, materi yang diajarkan, model dan media yang akan digunakan dalam pembelajaran, dan rencana penelitian. Persiapan yang dilakukan peneliti untuk meningkatkan keterampilan menulis cerita fantasi pada peserta didik kelas VII5, yaitu (1) melakukan kolaborasi dengan guru bahasa Indonesia mengenai rencana penelitian yang akan dilakukan, (2) menyusun rencana pelaksanaan pembelajaran keterampilan menyusun teks cerita fantasi, (3) membuat dan menyiapkan instrumen penilaian berupa instrumen tes dan instrumen nontes, (4) mempersiapkan bahan pembelajaran yang dibutuhkan peserta didik selama proses pembelajaran. 


\section{Tindakan Siklus I}

Pertama adalah tahap pendahuluan. Dalam tahap ini guru melakukan kegiatan pendahuluan dengan cara mengondisikan peserta didik agar siap mengikuti kegiatan pembelajaran. Kegiatan ini diawali dengan berdoa bersama sebagai wujud dari sikap religius, kemudian guru melakukan apersepsi, menyampaikan tujuan pembelajaran, memberikan penjelasan tentang manfaat menguasai materi pembelajaran, serta menyampaikan materi dan langkah-langkah pembelajaran yang akan dilakukan.

Kedua adalah kegiatan inti. Kegiatan inti pembelajaran menggunakan model Discovery Learning yang dilakukan pada siklus I, yaitu (1) peserta didik membentuk kelompok belajar, tiap kelompok terdiri atas empat sampai lima peserta didik dengan tertib, (2) guru atau peneliti memberi stimulus berupa teks fantasi, (3) setiap kelompok mengamati dan membaca contoh teks fantasi yang telah diberikan oleh guru atau peneliti, (4) peserta didik bertanya jawab mengenai perbedaan cerita fantasi dengan teks jenis lain, (5) setiap kelompok diinstruksikan untuk mengidentifikasi struktur teks, isi, kaidah bahasa, dan tema pada cerita fantasi pada Lembar Kerja Peserta Didik (LKPD) yang dibagikan (6) peserta didik bertanya jawab mengenai langkah-langkah menyusun teks cerita fantasi, (7) Setiap kelompok menentukan struktur teks, isi, kaidah bahasa, dan tema pada cerita fantasi. (8) setelah itu masing-masing peserta didik menyususn cerita fantasi yang dikembangkan masing-masing berdasarkan cerita yang telah dibaca, (9) setelah menyususn teks cerita fantasi kemudian dikomunikasikan di depan kelas.

Kegiatan penutup pada pertemuan pertama pembelajaran menyusun teks cerita fantasi secara tertulis dilakukan dengan langkah (1) peserta didik bersama guru menyimpulkan materi pembelajaran yang telah dipelajari (2) peserta didik mengerjakan evaluasi yang diberikan oleh guru, (3) peserta didik merefleksi penguasaan materi yang telah dipelajari dengan membuat catatan penguasaan materi, (4) peserta didik menyepakati tugas yang harus dilakukan berkaitan dengan menyusun teks cerita fantasi secara tertulis.

\section{Perencanaan Siklus II}

Setelah dilakukan refleksi pada siklus I diketahui kekurangan kekurangan yang ada pada proses pembelajaran siklus I. Berdasarkan kekurangan yang ada, dilakukan perbaikan dalam menyusun perencanaan pada siklus II. Perbaikan pada siklus I meliputi (1) perbaikan menyusun rencana pelaksanaan pembelajaran keterampilan menyusun teks cerita fantasi secara tertulis, (2) menyiapkan materi pembelajaran, (3) menyiapkan instrumen tes yang berupa unjuk kerja beserta kriterianya, pedoman observasi, pedoman wawancara, pedoman jurnal, dan pedoman dokumentasi, (4) berkoordinasi dengan guru mata pelajaran bahasa Indonesia tentang kegiatan pembelajaran keterampilan menyusun teks cerita fantasi secara tertulis. Rencana disusun semaksimal mungkin sebagai upaya penyempurnaan dan perbaikan atas rencana sebelumnya. Perbaikan rencana ini diharapkan dapat meningkatkan hasil pembelajaran keterampilan menyusun teks cerita fantasi secara tertulis.

\section{Tindakan siklus II}

Tindakan siklus II merupakan perbaikan langkah pembelajaran kegiatan inti dari tindakan siklus I. Langkah pembelajaran pada kegiatan inti yang dilakukan pada siklus II adalah pembelajaran menggunakan model Discovery Learning dan media Audio 
Visual (powerpoint dan video cuplikan cerita fantasi) yang dilakukan pada siklus II, yaitu (1) peserta didik membentuk kelompok belajar, tiap kelompok terdiri atas dua sampai tiga peserta didik dengan tertib, (2) guru atau peneliti memberi stimulus berupa teks fantasi, (3) setiap kelompok mengamati dan membaca contoh teks fantasi yang telah diberikan oleh guru atau peneliti, (4) peserta didik bertanyajawab mengenai perbedaan cerita fantasi dengan teks jenis lain, (5) setiap kelompok diinstruksikan untuk mengidentifikasi struktur teks, isi, kaidah bahasa, dan tema pada cerita fantasi pada Lembar Kerja Peserta Didik (LKPD) yang dibagikan (6) peserta didik bertanya jawab mengenai langkah-langkah menyusun teks cerita fantasi, (7) Setiap kelompok menentukan struktur teks, isi, kaidah bahasa, dan tema pada cerita fantasi. (8) setelah itu masing-masing peserta didik menyususn cerita fantasi yang dikembangkan masingmasing berdasarkan cerita yang telah dibaca, (9) setelah menyususn teks cerita fantasi kemudian dikomunikasikan di depan kelas.

\section{PEMBAHASAN}

Penelitian tindakan kelas ini dilaksanakan dnegan menggunakan tindakan berupa siklus I dan siklus II. Hasil penelitian ini berupa hasil tes keterampilan menyusun teks cerita fantasi. Hasil tes tersebut disajikan dalam bentuk data kuantitatif. Hasil nontes berupa hasil observasi, jurnal peserta didik, dan guru, wawancara, dan dokumentasi foto selama proses pembelajaran berlangsung. Hasil nontes ini disajikan ke dalam bentuk data kualitatif.

\section{Tindakan Siklus I}

Siklus I dilaksanakan pada hari selasa tanggal 10 September 2019 dan dilakukan dalam satu kali pertemuan. Selaras dengan penelitian yang direncanakan, tahapan siklus I mencakup (1) perencanaan, (2) pelaksanaan tindakan, (3) observasi, dan (4) refleksi.

Perencanaan

Perencanaan dilakukan melalui diskusi antara peneliti dengan guru bahasa dan sastra Indonesia yang bertindak sebagai kolaborator. Pada siklus I ini dilaksanakan perencanaan sebagai berikut; 1) Menyiapkan materi yang berkaitan dengan pembelajaran menulis cerita fantasi yang akan disampaikan pada siswa, 2) Menyiapkan Rencana Pelaksanaan Pembelajaran (RPP) yang disusun peneliti dengan mendapat bimbingan dan persetujuan guru mata pelajaran, 3)Menyiapkan media yang digunakan yaitu media Audio Visual. Pada siklus I ini Audio Visual yang akan ditunjukkan adalah berupa cuplikan film animasi berupa Bima putra garuda, doraemon, ultraman, 4) Menyiapkan lembar tes yang akan digunakan oleh siswa untuk menulis cerita fantasi, 5) Menyiapkan sarana untuk pemutaran cuplikan film animasi yaitu laptop, LCD, pengeras suara.

Berdasarkan rencana tindakan yang akan dilaksanakan pada pertemuan pertama siklus I yaitu penyampaian materi tentang cerita fantasi. Cerita fantasi yang disampaikan luas pada cerita yang familiar yaitu film kartun dan super hero. Sebelum proses pembelajaran dimulai, peneliti membagikan bahan ajar dan membagi peserta didik dalam beberapa kelompok untuk berdiskusi membahas cerita fantasi. Tes yang digunakan dalam penelitian ini berupa tes menyusun teks cerita pendek menggunakan model Discovery Learning dan Audio Visual. Tes ini dijadikan tolok ukur peningkatan keterampilan menyusun teks cerita fantasi menggunakan model Discovery Learning dan media Audio Visual. 
Berdasarkan hasil penelitian diketahui sebagian peserta didik menunjukkan ketercapaian indikator sikap sosial dalam pembelajaran menyusun teks cerita pendek menggunakan model Discovery Learning dan media Audio Visual. Dalam pembelajaran ini tercatat 18 atau $67 \%$ peserta didik mampu melakukan kegiatan tanpa ragu-ragu ketika mengerjakan tugas atau saat presentasi, 20 atau sebesar $74 \%$ peserta didik berani mengajukan pertanyaan, berpendapat dan memberi saran teman, 23 atau 85\% peserta didik berani mengakui jika mengalami kesulitan dalam pembelajaran, 17 atau $63 \%$ peserta didik aktif dalam diskusi kelompok, 17 atau $63 \%$ peserta didik mampu mengerjakan tugas sesuai dengan kesepakatan yang telah ditentukan, 24 atau 89\% peserta didik menghormati guru, 22 atau $81 \%$ peserta didik mampu menggunakan bahasa yang santun saat bertanya, menyampaikan pendapat, menyanggah, memberi saran, ataupun mengkritik, dan 27 atau $100 \%$ peserta didik tidak berkata-kata kotor, kasar, dan takabur selama proses pembelajaran menyusun teks cerita pendek berlangsung.

\section{Refleksi Siklus I}

Pada tahap refleksi ini, mahasiswa peneliti dan kolaborator dalam hal ini guru mata pelajaran bahasa Indonesia berdiskusi dan mengevaluasi mengenai proses dan hasil pembelajaran menulis cerita fantasi dengan metode Discovery Learning yang telah dilakukan pada siklus I ini. Dalam pelaksanaan siklus 1, hasil yang didapati kurang memuaskan untuk itu ada pembenahan pada siklus 2 yang dipaparkan dalam perencanaan siklus 2 .

Kelemahan pada aspek kesesuaian isi cerita fantasi adalah peserta didik kebingungan mengembangkan judul, menentukan jalan dan konflik cerita fantasi. Berdasarkan jurnal peserta didik sebagian peserta didik menyatakan kesulitan dalam menyusun teks cerita fantasi dengan memerhatikan struktur teks cerita fantasi. Solusi dari permasalahan tersebut adalah peneliti memberikan stimulus kepada peserta didik berupa contoh-contoh permasalahan yang dapat dikembangkan menjadi teks cerita fantasi yang menarik bagi mereka.

Kelemahan pada aspek kelengkapan dan kesesuaian struktur teks cerita fantasi adalah dalam menyusun teks cerita fantasi peserta didik kurang dapat mengembangkan struktur teks cerita fantasi dengan baik. Solusi untuk permasalahan tersebut adalah dengan memberikan penjelasan kembali dan memberikan contoh implementasi struktur teks cerita pendek dalam teks cerita fantasi.

Kelemahan pada aspek ketepatan pilihan kata adalah peserta didik kurang tepat dalam memilih diksi pada suatu kalimat. Hal ini terjadi hampir sebagian peserta didik. Solusi yang digunakan adalah 1) peserta didik harus mengetahui makna diksi yang dipilih, 2) peserta didik harus membaca kembali teks cerita fantasi yang telah disusun untuk memastikan diksi yang dipilih dalam setiap kalimatnya sudah tepat dan tidak bermakna ganda.

\section{Tindakan Siklus II}

Pada siklus II dilaksanakan pada hari Rabu, tanggal 18 September 2019, tindakan yang akan diberikan hampir sama dengan yang dilakukan pada siklus I. Hanya ada beberapa hal saja yang perlu diperbaiki dan lebih diperhatikan lagi. Perencanaan dan persiapan yang dilakukan adalah sebagai berikut; 1) Menyiapkan materi yang akan disampaikan, materi yang disampaikan terutama mengenai aspek penulisan dongeng yang masih kurang dipahami oleh siswa, seperti aspek isi cerita dan penyajian serta 
aspek kebahasaan, 2) Menyiapkan Rencana Pelaksanaan Pembelajaran (RPP) siklus II, 3) Menyiapkan sarana untuk media Audio Visual presentasi yaitu laptop, LCD, dan Sound System, 2) Menyiapkan media presentasi dan sebuah film lengkap dengan alur cerita yang dipotong yang akan diputar. Pada siklus II, video cerita fantasi berpusat pada cerita kepahlawanan, yaitu Aquaman dengan alih suara bahasa Indonesia agar lebih dipahami peserta didik, 3) Menyiapkan lembar tes yang akan digunakan oleh siswa untuk menulis cerita fantasi, 4) Menyiapkan lembar pengamatan, catatan lapangan, dan alat dokumentasi.

Perlakuan siklus I dan siklus II tidak jauh berbeda hanya saja setelah dilakukan refleksi, maka pembelajaran dilakukan dengan memfokuskan contoh tayangan cuplikan film Aquaman dan pemberian bahan ajar serta pendampingan dalam penyusunan cerita fantasi terlihat adanya perubahan.

Berdasarkan hasil siklus II diketahui sebagian besar peserta didik sudah menunjukkan ketercapaian indikator sikap sosial dalam pembelajaran menyusun teks cerita pendek menggunakan model Discovery Learning dan media dongeng. Dalam pembelajaran ini tercatat 22 peserta didik atau $81 \%$ melakukan kegiatan tanpa raguragu, 21 peserta didik atau $78 \%$ berani bertanya, berpendapat, dan menjawab pertanyaan, 23 peserta didik atau 85\% mengakui jika mengalami kesulitan dalam pembelajaran, 20 peserta didik atau 74\% aktif dalam diskusi kelompok, 23 peserta didik atau 85\% mengerjakan tugas sesuai kesepakatan, 25 peserta didik 93\% menghormati guru dan peserta didik lain, 24 peserta didik atau 89\% menggunakan bahasa yang santun saat bertanya, menyampaikan pendapat, menyanggah, memberi saran, ataupun mengkritik, dan 27 peserta didik atau 100\% tidak berkata-kata kotor, kasar, dan takabur. Hasil jurnal siklus II mengalami perubahan yang signifikan dari siklus I. Sebagian besar peserta didik mengerjakan tugas tanpa ragu-ragu. Peserta didik mengerjakan tugas menyusun teks cerita fantasi dengan percaya diri dan tidak kebingungan saat akan menyusun teks cerita fantasi.

\section{Refleksi Siklus II}

Dari hasil tersebut, kelemahan yang dialami pada siklus I sudah dapat ditingkatkan pada siklus II. Peserta didik sudah terbiasa untuk menjawab salam dan sapa dari guru atau dari peserta didik lain. Peserta didik yang awalnya tidak terbiasa mengucapkan salam sebelum presentasi menjadi terbiasa. Kelemahan yang dialami pada siklus I sudah ditingkatkan pada siklus II. Hasilnya sebagai berikut, (1) sebagian besar peserta didik terlihat bersemangat dan percaya diri menyusun teks cerita pendek, (2) sebagian besar peserta didik berani bertanya ataupun menjawab pertanyaan dengan tunjuk tangan terlebih dahulu, (3) sebagian besar peserta didik yang awalnya belum mau mengakui kesulitan yang dialami menjadi lebih reflektif, hanya sebagian kecil peserta didik yang belum mau mengakui kesulitan tapi hasilnya masih rata-rata dengan yang lain; (4) hampir semua peserta didik menjadi lebih aktif dalam diskusi kelas; (5) hampir semua peserta didik menyelesaikan tugas sesuai kesepakatan; (6) hampir semua peserta didik sudah menggunakan bahasa yang santun saat bertanya, menyampaikan pendapat, menyanggah, memberi saran, ataupun mengkritik. Berdasarkan hasil tes dan nontes peserta didik dalam pembelajaran menyusun teks cerita pendek menggunakan model Discovery Learning dan media audio visual secara keseluruhan menunjukkan bahwa peserta didik tertarik. Penggunaan model Discovery Learning dan media Audio Visual memudahkan peserta didik dalam menyusun teks cerita pendek meskipun sebagian kecil peserta didik menyatakan terlalu banyak menulis, tetapi hasil tes peserta didik 
menunjukkan hasil yang baik. Dari hasil tes dan nontes yang telah dicapai peserta didik, proses pembelajaran menyusun teks cerita fantasi pada siklus II telah berhasil meningkatkan kemampuan peserta didik dalam menyusun teks cerita fantasi sehingga tidak perlu lagi dilakukan pelaksanaan siklus berikutnya.

\section{KESIMPULAN}

Tindakan siklus I sesuai dengan Kriteria Ketuntasan Minimal (KKM) pada mata pelajaran Bahasa Indonesia di kelas VII5 SMP Negeri 3 Ambon adalah 70. Pada pelakasanaan Siklus I yang telah dilaksnakan, peserta didik yang memenuhi ketuntasan minimal dari ketiga aspek dalam menyusun cerita fantasi sebanyak 5 siswa atau sebesar $18,52 \%$, dan yang belum mencapai KKM ada sebanyak 22 siswa atau sebesar $81,48 \%$. Untuk siklus II yang dapat menyusun cerita fantasi dan tuntas KKM pada kelas VII5 sebanyak 22 peserta didik atau $81,48 \%$. Dan siswa yang belum tuntas sebanyak 5 peserta didik atau $18,52 \%$. Dari kedua penelitian ini didapatkan hasil bahwa ada peningkatan $62,96 \%$.

Selain itu dari segi sikap sosial kelas VII5 SMP Negeri 3 Ambon mengalami perubahan dan peningkatan setelah mengikuti pembelajaran menyusun teks cerita pendek menggunakan model Discovery Learning dan media Audio Visual. Perubahan sikap sosial peserta didik meliputi (1) melakukan kegiatan tanpa ragu-ragu ketika mengerjakan tugas atau melakukan presentasi, (2) berani mengajukan pertanyaan, berpendapat, ataupun menjawab pertanyaan, (3) mengakui jika mengalami kesulitan dalam pembelajaran, (4) aktif dalam diskusi kelompok, (5) mengerjakan tugas sesuai kesepakatan, (6) menghormati guru dan peserta didik lain, (7) menggunakan bahasa yang santun saat bertanya, menyampaikan pendapat, menyanggah, memberi saran atau mengkritik teman, (8) tidak berkata-kata kotor, kasar, dan takabur.

\section{DAFTAR PUSTAKA}

Abidin, Yunus. 2012. Pembelajaran Bahasa Berbasis Pendidikan Karakter. Bandung: Refika Aditama.

Afra, Afifah. 2007. How To Be A Smart Writer. Surakarta: Indiva Media Kreasi.

Akhadiah, Sabarti dkk. 1988. Pembinaan Kemampuan Menulis Bahasa Indonesia. Jakarta: Erlangga.

Ampera, Taufik. 2010. Pengajaran Sastra. Bandung: Widya Padjadjaran.

Castronova, Joyce A. Discovery Learning for the 21st Century: What is it and how does it compare to traditional learning in effectivenes in the 21st Century?http://teach.valdosta.edu/are/Litreviews/vollnol/castronova_litr.pdf. Diunduh pada tanggal 20 Agustus 2019.

Eka Ihsanudin. Pembelajaran Model Discovery Learning. httpp://embelajaranmodel20discoverylearning.html. diunduh pada 17 September 2019.

Kementerian Pendidikan dan Kebudayaan. 2013a. Bahasa Indonesia Wahana Pengetahuan Kelas VII. Jakarta: Kementerian Pendidikan dan kebudayaan. 
Kementerian Pendidikan dan Kebudayaan. 2013b. Bahasa Indonesia Wahana Pengetahuan: Buku Guru. Jakarta: Kementerian Pendidikan dan kebudayaan.

Winda Hayu Pamungkas, 2014. "Peningkatan Keterampilan Menyusun Teks Cerita Pendek Secara Tertulis Menggunakan Model Discovery Learning Dan Media Dongeng Pada Peserta Didik Kelas VII Aisyah Smpit Bina Amal Gunungpati Semarang”. Skripsi. Semarang: UNNES. 
Peningkatan Keterampilan Menulis Teks Cerita Fantasi dengan Model Discovery Learning dan Media Audio Visual pada Siswa Kelas VII5 SMP Negeri 3 Ambon 